\title{
PENDIDIKAN PLURALISME MELALUI KURIKULUM PENDIDIKAN AGAMA ISLAM BERBASIS KEIMAJEMUKAN
}

\author{
Mutakallim \\ Dosen Filsafat Pendidikan UIN Alauddin Makassar \\ DPK Universitas Muhammadiyah Makassar
}

\begin{abstract}
Experts and religious leaders have tried everything in order to create an intimate and harmonious relationship between religious people in this famous, very pluralistic country of Indonesia. Through writings both books, magazines, journals and even through seminars and pulpits of sermons always suggest the importance of cooperation and dialogue between religious groups. Although it seems, their suggestions have not had such an exciting effect. To gain success for the realization of the noble goal of lasting peace and brotherhood among people who in reality have different religions and faiths, it is necessary to have the courage to invite them to make changes in the field of education, especially through a diversity-based curriculum. Because, through a curriculum like this, it is possible to be able to dismantle the theology of each religion which has tended to be displayed exclusively and dogmatically. A theology which usually only claims that only religion can build worldly welfare and usher in humans in God's heaven. The doors and rooms of heaven are only one that cannot be opened and entered except with the religion that he embraces. Even though such aology, we must admit, is something that is very worrying and can disturb the harmony of the people of religions in the present pluralistic era. An era in which all societies with all their elements are required to be interdependent and collect their fate together in order to create lasting peace. Here lies the challenge for religion (including Islam) to redefine itself in the midst of other religions. Or by borrowing the language John Lyden, an expert on religions, is "what should I think about other religions than one's own? What should a Muslim think about non-Muslims. Is it still as an enemy or as a friend. Of course there is still the presumption of one religion with another as an enemy. It must be thrown away. Isn't in fact all of us as brothers and friends? Islam through the Qur'an and its Hadith teaches tolerant attitudes. In addition, the importance of reforming the PAI curriculum by presenting the face of tolerant Islam can be explained from the point of view of perennial philosophy, essentialism and progressiveness. In the view of perennialism the curriculum is "construct" which is built to transfer what has happened in the past to the next generation to be preserved, continued or developed. While in the philosophical perspective of progressivism, the position of the curriculum is to build a future life in which the past, present, and various plans for the development and development of the nation are used as the basis for developing future life. From this it is possible to teach the principles of humanist, democratic and equitable Islamic teachings to students. A principle of Islamic teachings that is very relevant to enter the future of the world which is characterized by the existence of cultural and religious diversity.
\end{abstract}

Keywords: Islam, Education, Curriculum, Pluralism 


\section{PENDAHULUAN}

$\mathrm{E}$ ntah kenapa ketika mendengar kata "pluralisme", sebagian dari kebanyakan umat Islam harus menutup kuping mereka rapat-rapat. Seolah-olah pluralisme ini telah dianggap oleh mereka, sebagai "hantu" yang perlu ditakuti dan dijauhi. Orang yang mencoba menjelaskan dan mewacanakannya pun juga terkena imbasnya, tak sedikit dari mereka yang telah dihujat, dicaci maki dan dikucilkan, tidak hanya dianggap sebagai antek-antek Barat, tetapi juga telah "diklaim" sebagai calon penghuni neraka.

Saya memahami, kenapa mereka sampai berbuat demikian. Karena kebanyakan dari mereka - saya yakin - belum mengetahui secara komprehensif substansi pluralisme itu sendiri. Disamping itu, mereka juga sudah terburu-buru untuk bersikap antipati dan penuh kecurigaan, kalau pluralisme ini adalah produk Barat, yang pasti sesat dan menyesatkan. Memang, tidak bisa dipungkiri dalam realitas kesejarahannya pluralisme ini berasal dari Barat. Tetapi kalau kemudian paham ini, mampu memberikan kontribusi positif bagi terciptanya persahabatan dan perdamaian bagi masyarakat agama, kenapa harus ditampik, inilah pertanyaannya. ${ }^{1}$

Kalau mau jujur, bukankah selama ini kita telah ikut merasakan dan menikmati produk-produk Barat akibat keunggulan IPTEK yang dimilikinya? Janganlah menutup mata, kalau kita selama ini bisa berkomunikasi jarak jauh dengan HP, faximile dan internet serta bisa bepergian ke seluruh dunia (termasuk menunaikan ibadah Haji dan Umrah ke Mekah) dengan naik pesawat, mobil dan kapal—adalah berkat Barat.

Dengan begitu, dapatlah dikatakan bahwa sesuatu yang datang dari Barat ternyata tidak selamanya jelek dan bertentangan dengan Islam. Semuanya sebenarnya tergantung bagaimana cara menyikapi dan mempergunakannya. Sebagai contoh, kalau manusia tidak dapat secara arif dan bijaksana mempergunakan saints dan teknologi, maka hal ini pastilah akan berimplikasi negatif bagi kehidupan manusia, yaitu menyebabkan terjadinya krisis dalam berbagai bidang kehidupan. Bukankah contoh seperti ini juga berlaku bagi paham pluralisme?

Namun haruslah diakui, bahwa Barat tentu saja bukanlah "segala-galanya", sehingga semua pikiran, perilaku, budaya serta norma-norma harus berkiblat dengan Barat. Kalau tidak mengikuti trend Barat, dikatakan "kampungan" alias ketinggalan zaman, karena pada kenyataannya, terdapat tradisi dan kebudayaan yang berasal dari Barat yang tidak sesuai dengan kultur Islam seperti cara berpakaian yang banyak mengundang syahwat, makanan dan minuman beralkohol, dan free sex. Alangkah baiknya kalau kita memang seselektif mungkin untuk mencoba memilih dan memilah budaya Barat tersebut, yang baik kita tiru, dan yang tidak sesuai dengan Islam kita buang jauh-jauh. ${ }^{2}$

1 Azra, Azyumardi, 1998, Esai-esai Intelektual Muslim dan Pendidikan Islam, Tradisi dan Modernisme Menuju Milenium Baru, Jakarta: Logos Wacana Ilmu, 1998), h. 72.

${ }^{2}$ Mohammed Arkoun, Islam Kontemporer: Menuju Dialog antar Agama, (Yogyakarta: Pustaka Pelajar, 2001), h. 102. 
Apakah sebenarnya pluralisme itu? kalau melacak dari beberapa sumber, dapatlah didefenisikan bahwa pluralisme adalah sebuah paham tentang pluralitas. Paham, bagaimana melihat keragaman dalam agama-agama, mengapa dan bagaimana memandang agama-agama, yang begitu banyak dan beragam. Apakah hanya ada satu agama yang benar atau semua agama benar. Pengakuan terhadap pluralisme agama dalam suatu komunitas umat beragama menjanjikan dikedepankannya prinsip inklusifitas yang bermuara pada tumbuhnya kepekaan terhadap berbagai kemungkinan unik yang bisa memperkaya usaha manusia dalam mencari kesejahteraan spritual dan moral. Gagasan bahwa manusia adalah satu umat, seperti ini menurut Sachedina "merupakan dasar pluralisme teologis yang menuntut adanya kesetaraan hak yang diberikan Tuhan bagi semua. Manusia tetap merupakan "satu bangsa" berdasarkan kemanusiaan yang sama-sama mereka miliki. Karena itulah diperlukan suatu "etika global" yang bisa memberikan dasar pluralistik untuk memperantarai hubungan antar agama di antara orang-orang yang memiliki komitmen spritual berbeda".

Bahkan menurut al-Qur'an sendiri, pluralitas adalah salah satu kenyataan objektif komunitas umat manusia, sejenis hukum Allah atau Sunnah Allah, dan bahwa hanya Allah yang tahu dan dapat menjelaskan, di hari akhir nanti, mengapa manusia berbeda satu dari yang lain, dan mengapa jalan manusia berbeda-beda dalam beragama. Dalam al-Qur'an disebutkan, yang artinya: “Untuk masing-masing dari kamu (umat manusia) telah kami tetapkan Hukum (Syari'ah) dan jalan hidup (minhaj). Jika Tuhan menghendaki, maka tentulah ia jadikan kamu sekalian umat yang tunggal (monolith). Namun Allah jadikan kamu sekalian berkenaan dengan hal-hal yang telah dikaruniaNya kepada kamu. Maka berlombalah kamu sekalian untuk berbagai kebajikan. Kepada Allahlah tempat kalian semua kembali; maka Ia akan menjelaskan kepadamu sekalian tentang perkara yang pernah kamu perselisihkan".3

Demikianlah prinsip dasar Al-Qur'an yang berkaitan dengan masalah pluralisme dan toleransi. Paling tidak, dalam tataran konseptual, Al-Qur'an telah memberi resep atau arahan-arahan yang sangat diperlukan bagi manusia Muslim untuk memecahkan masalah kemanusiaan universal, yaitu realitas pluralitas keberagamaan manusia dan menuntut supaya bersikap toleransi terhadap kenyataan tersebut demi tercapainya perdamaian di muka bumi. Karena Islam menilai bahwa syarat untuk membuat keharmonisan adalah pengakuan terhadap komponen-komponen yang secara alamiah berbeda.

Demi tujuan itu, maka pendidikan sebenarnya masih dianggap sebagai instrumen penting. Sebab, "pendidikan" sampai sekarang masih diyakini mempunyai peran besar dalam membentuk karakter individu-individu yang dididiknya, dan mampu menjadi "guiding light" bagi generasi muda penerus bangsa. Dalam konteks inilah, pendidikan agama sebagai media penyadaran umat perlu membangun teologi inklusif dan pluralis, demi harmonisasi agama-agama (yang telah menjadi kebutuhan masyarakat agama

\footnotetext{
${ }^{3}$ Kementerian Agama RI., al-Qur'an dan Terjemahnya, (Surabaya: Karya Agung, 2006), h. 143.
} 
sekarang).

Hal tersebut dengan suatu pertimbangan, bahwa salah satu peran dan fungsi pendidikan agama diantaranya adalah untuk meningkatkan keberagamaan peserta didik dengan keyakinan agama sendiri, dan memberikan kemungkinan keterbukaan untuk mempelajari dan mempermasalahkan agama lain sebatas untuk menumbuhkan sikap toleransi. ${ }^{4}$ Ini artinya, pendidikan agama pada prinsipnya, juga ikut andil dan memainkan peranan yang sangat besar dalam menumbuh-kembangkan sikap-sikap pluralisme dalam diri siswa. Pendidikan agama adalah sebagai wahana untuk mengekplorasi sifat dasar keyakinan agama di dalam proses pendidikan dan secara khusus mempertanyakan adanya bagian dari pendidikan keimanan dalam masyarakat. Pendidikan agama dengan begitu, seharusnya mampu merefleksikan persoalan pluralisme, dengan mentransmisikan nilai-nilai yang dapat menumbuhkan sikap toleran, terbuka dan kebebasan dalam diri generasi muda.

Organisasi sekolah dan atmosfirnya harus mampu mewujudkan jalan menuju kehidupan secara personal dan sosial. Sekolah harus dapat mempraktekkan sesuatu yang telah diajarkanya. Dengan demikian, lingkungan sekolah dapat dijadikan percontohan oleh murid-murid untuk learning by doing. Di dalam sekolah, peserta didik seharusnya dapat mempelajari adanya kurikulum-kurikulum umum di dalam kelas-kelas heterogen. Hal ini diperlukan guna mendorong adanya persamaan ideal, membangun perasaan persamaan, dan memastikan adanya input dari peserta didik yang memiliki latar belakang berbeda. Melalui pengembangan kurikulum pendidikan agama Islam berbasis kemajemukan dengan mempertimbangkan pengembangan komponen-komponen, ya bahan, metode, peserta didik, media, lingkungan, dan sumber belajar maksud dan tujuan pendidikan pluralisme, dengan begitu akan dapat dijadikan sebagai jawaban atau solusi alternatif bagi keinginan untuk merespon persoalan-persoalan di atas. Sebab dalam pendidikanya, pemahaman Islam yang hendak dikembangkan oleh pendidikan berbasis pluralisme adalah pemahaman dan pemikiran yang bersifat inklusif.

Melalui sistem pendikikanya, sebuah pendidikan yang berbasis pluralisme akan berusaha memelihara dan berupaya menumbuhkan pemahaman yang inklusif pada peserta didik. Dengan suatu orientasi untuk memberikan penyadaran terhadap para peserta didiknya akan pentingnya saling menghargai, menghormati dan bekerja sama dengan agama-agama lain, dalam batas wilayah non ibadah dan non aqidah.

\section{BERSIKAP 'TOLERAN' TERHADAP AGAMA LAIN}

Secara umum, pandangan Islam terhadap agama lain (Ahli Kitab-pen) sangat positif dan sangat kontruktif. Hal ini dapat dilihat dari nilai dan ajarannya yang memberikan peluang dan mendorong kepada umat Islam untuk dapat melakukan interaksi sosial, kerja sama dengan mereka, selama interaksi sosial itu tidak memasuki

${ }^{4}$ Sealy, Structure and Creativity in Religion. (The Houge the Netherlands: Mountan Publisher, 1986), h. 43-44 
areal aqidah. Perintah Islam agar umatnya bersikap toleran, bukan hanya pada agama Yahudi dan Kristen, tetapi juga kepada agama-agama lain. Ayat 256 surat al-Baqarah mengatakan bahwa tidak ada paksaan dalam soal agama karena jalan lurus dan benar telah dapat dibedakan dengan jelas dari jalan salah dan sesat. Terserahlan kepada manusia memilih jalan yang dikehendakinya. Telah dijelaskan mana jalan benar yang akan membawa kepada kesengsaraan. Manusia merdeka memilih jalan yang dikehendakinya. Kemerdekaan ini diperkuat oleh ayat 6 surah al-Kafirun yang mengatakan: Bagimulah agamamu dan bagiku agamaku.

Demikianlah beberapa prinsip dasar al-Qur'an yang berkaitan dengan masalah pluralisme dan anjuran untuk dapat menunjukkan sikap saling menghormati, ramah dan bersahabat dengan agama Kristen, secara khusus. Dengan begitu, jauh-jauh hari, alQur'an sesungguhnya telah mensinyalir akan munculnya bentuk "truth claim". ${ }^{5}$ Baik itu dalam wilayah intern umat beragama maupun wilayah antar-umat beragama. Keduaduanya, sama-sama tidak favourable dan tidak kondusif bagi upaya membangun tata pergaulan masyarakat pluralistik yang sehat. Oleh al-Qur'an, kecendrungan manusia untuk mengantongi "truth claim" yang potensial untuk ekplosif dan destruktif itu, kemudian dinetralisir dalam bentuk anjuran untuk selalu waspada terhadap bahaya ektrimitas dalam berbagai bentuknya. Dan manusia Muslim sendiri dituntut untuk senantiasa merendahkan hati dan bersedia dengan "kebenaran" (al-haq) dan kesabaran (al-Shabar) dalam setiap langkah dalam perjalanan hidupnya (surat al-Ashr: 1-3).

Paling tidak, dalam dataran konseptual, al-Qur'an telah memberi resep atau arahan-arahan yang sangat diperlukan bagi manusia Muslim untuk memecahkan masalah kemanusiaan universal, yaitu realitas pluralitas keberagamaan manusia dan menuntut supaya bersikap toleransi terhadap kenyataan tersebut demi tercapainya perdamaian di muka bumi. Karena Islam menilai bahwa syarat untuk membuat keharmonisan adalah pengakuan terhadap komponen-komponen yang secara alamiah berbeda. Dengan begitu, dapat pula dikatakan konsepsi pluralisme dalam Islam sudah terbawa pada misi awal agama ini diturunkan, yakni membawa kasih terhadap seluruh alam tanpa batas-batas atau benturan-benturan dimensi apapun. Semua orang yang mengaku Islam haruslah menunjukkan sikap saling "mengasihi" kepada sesama manusia. Karena seseorang bisa disebut sebagai seorang muslim, menurut kanjeng nabi adalah Al-Muslimu man salima al-muslimuna min lisanihi wa yadihi. Maksudnya adalah seorang muslim yang senantiasa menebarkan sikap damai dan rasa aman dihati masyarakatnya. ${ }^{6}$

\section{KEGAGALAN PENDIDIKAN AGAMA}

Berangkat dari kesadaran adanya fenomena bahwa "satu Tuhan, banyak agama"

${ }^{5}$ M. Amin Abdullah, Studi Agama: Normativitas atau Historisitas, (Yogyakarta: Pustaka Pelajar, 1999), h. 68.

${ }^{6}$ Muhammad Afifi al-Hadi, al-Tarbiyah wa al-Taghoyyur al-Tsaqafi, (Kairo: Maktabah Angelo al-Mishriyyah, 1964), h. 89. 
merupakan fakta dan realitas yang dihadapi manusia sekarang. Maka, manusia sekarang harus didorong menuju kesadaran bahwa pluralisme memang sungguh-sungguh fitrah kehidupan manusia. Mendorong setiap orang untuk dapat menghargai "keanekaragaman" adalah sangat penting segera dilakukan, terutama sekali di negara Indonesia yang pluralistik ini. Dampak krisis multi-dimensional yang melandanya, menyebabkan bangsa Indonesia menghadapi berbagai problem sosial. Salah satu problem besar dimana peran agama menjadi sangat dipertanyakan adalah konflik etnis, kultur dan religius, atau yang lebih dikenal dengan SARA.

Kegagalan agama dalam memainkan perannya sebagai problem solver bagi persoalan SARA erat kaitanya dengan pengajaran agama secara eklusif. Maka, agar bisa keluar dari kemelut yang mendera bangsa Indonesia terkait persoalan SARA, adalah sudah saatnya bagi bangsa Indonesia untuk memunculkan wajah pendidikan agama yang inklusif dan humanis. Pada tataran teologis, dalam pendidikan agama perlu mengubah paradigma teologis yang pasif, tekstualis, dan eklusif. Menuju teologi yang saling menghormati, saling mengakui eksistensi, berfikir dan bersikap positif, serta saling memperkaya iman. Hal ini dengan tujuan untuk membangun interaksi umat beragama dan antarumat beragama yang tidak hanya bereksistensi secara harmonis dan damai, tetapi juga bersedia aktif dan pro-aktif kemanusiaan. Sebenarnya masyarakat Indonesia telah lama akrab dengan diktum Bhinneka Tunggal Ika. Namun sayangnya, konsep ini telah mengalami pemelintiran makna dan bias interpretasi, terutama sepanjang pemerintahan Orde Baru. Kebijakan sosial-politik saat itu cenderung uniformistik, sehingga tampaknya budaya milik kelompok dominanlah yang diajarkan dan disalurkan oleh sekolah dari satu generasi kepada generasi lainya.

Sekolah pada saat itu juga ditengarai hanya merefleksikan dan menggemakan stereotip dan prasangka antarkelompok yang sudah terbentuk dan beredar dalam masyarakat, tidak berusaha menetralisisir dan menghilangkanya. Bahkan, ada indikasi bahwa sekolah ikut mengembangkan prasangka dan mengeskalasi ketegangan antarkelompok melalui perundang-undangan yang mengkotak-kotakkan penyampaiaan pendidikan agama, isi kurikulum yang etnosentris, dan dinamika relasi sosial antarsekolah yang segregatif. ${ }^{7}$ Bukan tak mungkin segregating sekolah berdasarkan kepemelukan agama juga ikut memperuncing prasangka dan proses demonisasi antara satu kelompok dengan kelompok lainnya, baik secara langsung maupun atau tidak langsung .

Padahal, menurut S. Hamid Hasan, "keragaman sosial, budaya, ekonomi, dan aspirasi politik, dan kemampuan ekonomi adalah suatu realita masyarakat dan bangsa Indonesia. Namun demikian, keragaman sosial, budaya, ekonomi, dan aspirasi politik yang seharusnya menjadi faktor yang diperhitungkan dalam penentuan filsafat, teori, visi, pengembangan dokumen, sosialisasi kurikulum, dan pelaksanaan kurikulum,

${ }^{7}$ Lihat, Azyumardi Azra, 1998, Esai-esai Intelektual Muslim dan Pendidikan Islam, Tradisi dan Modernisme Menuju Milenium Baru, (Jakarta: Logos Wacana Ilmu, 1998), h. 156-157. 
nampaknya belum dijadikan sebagai faktor yang harus dipertimbangkan dalam pelaksanaan kurikulum pendidikan di negara kita". ${ }^{8}$ Maka, akibatnya, wajar manakala terjadi kegagalan dalam pendidikannya (termasuk pendidikan agama), terutama sekali dalam menumbuhkan sikap-sikap untuk menghargai adanya perbedaan dalam masyarakat.

Selain itu, Kautsar Azhari Noer seperti yang dikutip Imam Barnadib, menyebutkan, paling tidak ada empat faktor penyebab kegagalan pendidikan agama dalam menumbuhkan pluralisme. Pertama, penekananya pada proses transfer ilmu agama ketimbang pada proses transformasi nilai-nilai keagamaan dan moral kepada anak didik; kedua, sikap bahwa pendidikan agama tidak lebih dari sekedar sebagai "hiasan kurikulum" belaka, atau sebagai "pelengkap" yang dipandang sebelah mata; ketiga, kurangnya penekanan pada penanaman nilai-nilai moral yang mendukung kerukunan antaragama, seperti cinta, kasih sayang, persahabatan, suka menolong, suka damai dan toleransi; dan keempat, kurangnya perhatian untuk perhatikan untuk mempelajari agama-agama lain. ${ }^{9}$

Melihat realitas tersebut, bahkan ditambah dengan adanya banyak konflik, kekerasan, dan bahkan kekejaman yang dijalankan atas nama agama, sebagaimana tersebut di atas, seharusnyalah yang menjadi tujuan refleksi atas pendidikan agama adalah mampu melakukan transformasi kehidupan beragama itu sendiri dengan melihat sisi ilahi dan sosial-budayanya. Pendidikan agama harus mampu menanamkan cara hidup yang lebih baik dan santun kepada peserta didik. Sehingga sikap-sikap seperti saling menghormati, tulus, dan toleran terhadap keanekaragaman agama dan budaya dapat tercapai di tengah-tengah masyarakat plural.

\section{KURIKULUM PENDIDIKAN AGAMA ISLAM BERBASIS KEMAJEMUK- AN}

Pendidikan adalah salah satu bentuk perwujudan kebudayaan manusia yang dinamis dan sarat perkembangan, karena itu perubahan atau perkembangan pendidikan adalah hal yang memang seharusnya terjadi sejalan dengan perubahan budaya kehidupan. Perbaikan pendidikan pada semua tingkat perlu terus dilakukan sebagai antisipasi kepentingan masa depan. Pemikiran ini mengandung konsekuensi bahwa penyempurnaan atau perbaikan kurikulum pendidikan agama Islam adalah untuk mengantisipasi kebutuhan dan tantangan masa depan dengan diselaraskan terhadap perkembangan kebutuhan dunia usaha atau industri, perkembangan dunia kerja, serta perkembangan ilmu pengetahuan, teknologi, dan seni. Konsep yang sekarang banyak diwacanakan oleh banyak ahli adalah kurikulum pendidikan berbasis pluralisme.

Melihat realitas tersebut, maka disinilah letak pentingnya menggagas pendidikan

${ }^{8}$ S. Hamid Hasan, "Kesatuan dan Keragaman Agama Dalam Pandangan Hazrat Inayat Khan", dalam Jurnal Penelitian Agama, Nomor 21, TH. VIII Januari-April., h. 511

${ }_{9}^{9}$ Lihat Imam Barnadib, Filsafat Pendidikan: Sistem dan Metode, (Yogyakarta, Andi Ofset, 1994), h. $102-103$. 
Islam berbasis pluralisme dengan menonjolkan beberapa karakter sebagai berikut; pertama pendidikan Islam harus mempunyai karakter sebagai lembaga pendidikan umum yang bercirikan Islam. Artinya, di samping menonjolkan pendidikannya dengan penguasaan atas ilmu pengetahuan, namun karakter keagamaan juga menjadi bagian integral dan harus dikuasai serta menjadi bagian dari kehidupan siswa sehari-hari. Tentunya, ini masih menjadi pertanyaan, apakah sistem pendidikan seperti ini betulbetul mampu membongkar sakralitas ilmu-ilmu keagamaan dan dikhotomi keilmuan antara ilmu pengetahuan umum dan ilmu keagamaan. Kedua; Pendidikan Islam juga harus mempunyai karakter sebagai pendidikan yang berbasis pada pluralitas. Artinya, bahwa pendidikan yang diberikan kepada siswa tidak menciptakan suatu pemahaman yang tunggal, termasuk di dalamnya juga pemahaman tentang realitas keberagamaan. Kesadaran pluralisme merupakan suatu keniscayaan yang harus disadari oleh setiap peserta didik. Tentunya, kesadaran tersebut tidak lahir begitu saja, namun mengalami proses yang sangat panjang, sebagai realitas pemahaman yang komprehenship dalam melihat suatu fenomena. Ketiga; Pendidikan Islam harus mempunyai karakter sebagai lembaga pendidikan yang menghidupkan sistem demokrasi dalam pendidikan. Sistem pendidikan yang memberikan keluasaan pada siswa untuk mengekspresikan pendapatnya secara bertanggung jawab. Sekolah memfasilitasi adanya "mimbar bebas", dengan memberikan kesempatan kepada semua civitas untuk berbicara atau mengkritik tentang apa saja, asal bertanggung jawab. Tentunya, sistem demokrasi ini akan memberikan pendidikan pada siswa tentang realitas sosial yang mempunyai pandangan dan pendapat yang berbeda. Di sisi yang lain, akan membudayakan "reasoning" bagi civitas di lembaga pendidikan Islam. ${ }^{10}$

Perlunya membentuk pendidikan Islam berbasis pluralisme tersebut, sekali lagi merupakan suatu inisiasi yang lahir dari realitas sejarah pendidikan khususnya di Indonesia yang dianggap gagal dalam membangun citra kemanusiaan. Dimana umumnya, pendidikan umum hanya mencetak orang-orang yang pinter namun tidak mempunyai integritas keilmuan dan akhlaq ilmuan. Ini yang kemudian melahirkan para koruptor yang justru menjadi penyakit dan menyengsarakan bangsa ini. Di satu sisi, pendidikan agama yang ada hanya menciptakan ahli agama yang cara berpikirnya parsial dan sempit. Akhirnya, semakin banyak orang pinter ilmu agama semakin kuat pertentangan dan konflik dalam kehidupan. Inilah sistem pendidikan yang gagal dalam menciptakan citra kemanusiaan.

Untuk merealisasikan cita-cita pendidikan yang mencerdaskan seperti tersebut, lembaga pendidikan Islam perlu menerapkan sistem pengajaran yang berorientasi pada penanaman kesadaran pluralisme dalam kehidupan. Adapun beberapa program pendidikan yang sangat strategis dalam menumbuhkan kesadaran pluralisme adalah: pendidikan sekolah harus membekali para mahasiswa atau peserta didik dengan

${ }^{10}$ Lihat, Basri, Ghazali at al, 1991, An Integrated Education System In A Multifaith and MultiCultural Country, (Malaysia: Muslim Yuth Movement Malaysia, 1991), h. 98-99. 
kerangka (frame work) yang memungkinkannya menyusun dan memahami pengetahuan yang diperoleh dari lingkungannya. Karena masyarakat kita majemuk, maka kurikulum PAI yang ideal adalah kurikulum yang dapat menunjang proses siswa menjadi manusia yang demokratis, pluralis dan menekankan penghayatan hidup serta refleksi untuk menjadi manusia yang utuh, yaitu generasi muda yang tidak hanya pandai tetapi juga bermoral dan etis, dapat hidup dalam suasana demokratis satu dengan lain, dan menghormati hak orang lain.

Selain itu, perlu kiranya memperhatikan kurikulum sebagai proses. Ada empat hal yang perlu diperhatikan guru dalam mengembangkan kurikulum sebagai proses ini, yaitu; (1) posisi siswa sebagai subjek dalam belajar, (2) cara belajar siswa yang ditentukan oleh latar belakang budayanya, (3) lingkungan budaya mayoritas masyarakat dan pribadi siswa adalah entry behaviour kultur siswa, (4) lingkungan budaya siswa adalah sumber belajar. ${ }^{11}$ Dalam konteks deskriptif ini, kurikulum pendidikan mestilah mencakup subjek seperti: toleransi, tema-tema tentang perbedaan ethno-kultural dan agama: bahaya diskriminasi: penyelesaian konflik dan mediasi: HAM; demokrasi dan pluralitas; kemanusiaan universal dan subjek-subjek lain yang relevan.

Bentuk kurikulum dalam pendidikan agama Islam hendaknya tidak lagi ditujukan pada siswa secara individu menurut agama yang dianutnya, melainkan secara kolektif dan berdasarkan kepentingan bersama. Bila selama ini setiap siswa memperoleh pelajaran agama sesuai dengan agamanya, maka diusulkan agar lebih baik bila setiap siswa SLTP-PT memperoleh materi agama yang sama, yaitu berisi tentang sejarah pertumbuhan semua agama yang berkembang di Indonesia. Sedangkan untuk SD diganti dengan pendidikan budi pekerti yang lebih menanamkan nilai-nilai moral kemanusiaan dan kebaikan secara universal. Dengan materi seperti itu, di samping siswa dapat menentukan agamanya sendiri (bukan berdasarkan keturunan), juga dapat belajar memahami pluralitas berdasarkan kritisnya, mengajarkan keterbukaan, toleran, dan tidak eklusif, tapi inklusif. ${ }^{12}$

Amin Abdullah menyarankan "perlunya rekonstruksi pendidikan sosialkeagamaan untuk memperteguh dimensi kontrak sosial-keagamaan dalam pendidikan agama". ${ }^{13}$ Dalam hal ini, kalau selama ini praktek di lapangan, pendidikan agama Islam masih menekankan sisi keselamatan yang dimiliki dan didambakan oleh orang lain di luar diri dan kelompoknya sendiri-jadi materi pendidikan agama lebih berfokus dan sibuk mengurusi urusan untuk kalangan sendiri (individual atau private affairs). Maka, pendidikan agama Islam perlu direkonstruksi kembali, agar lebih menekankan proses edukasi sosial, tidak semata-mata individual dan untuk memperkenalkan konsep socialcontract. Sehingga pada diri peserta didik tertanam suatu keyakinan, bahwa kita semua sejak semula memang berbeda-beda dalam banyak hal, lebih-lebih dalam bidang akidah,

\footnotetext{
${ }^{11}$ Imam Barnadib, Filsafat Pendidikan: Sistem dan Metode, h. 522.

12 S. Hamid Hasan, "Kesatuan dan Keragaman Agama Dalam Pandangan Hazrat Inayat Khan", dalam Jurnal Penelitian Agama, Nomor 21, TH. VIII Januari-April., h. 156.

${ }^{13}$ Lihat, M. Amin Abdullah, Studi Agama: Normativitas atau Historisitas, h. 13-16.
} 
iman, credo, tetapi demi untuk menjaga keharmonisan, keselamatan, dan kepentingan kehidupan bersama, mau tidak mau, kita harus rela untuk menjalin kerjasama (cooperation) dalam bentuk kontrak sosial antar sesama kelompok warga masyarakat.

Pendek kata, agar maksud dan tujuan pendidikan agama Islam berbasis pluralisme dapat tercapai, kurikulumnya harus didesain sedemikian rupa dan favourable untuk semua tingkatan dan jenjang pendidikan. Namun demikain, pada level sekolah dasar dan menengah adalah paling penting, sebab pada tingkatan ini, sikap dan perilaku peserta didik masih siap dibentuk. Dan perlu diketahui, suatu kurikulum tidak dapat diimplementasikan tanpa adanya keterlibatan, pembuatan dan kerjasama secara langsung antara para pembuat kurikulum, penulis text book dan guru.

Langkah-langkah yang perlu diperhatikan oleh pembuat kurikulum, penulis text book dan guru untuk mengembangkan kurikulum PAI berbasis pluralisme di Indonesia, adalah sebagai berikut;

Pertama, mengubah filosofi kurikulum dari yang berlaku seragam seperti saat ini kepada filosofi yang lebih sesuai dengan tujuan, misi, dan fungsi setiap jenjang pendidikan dan unit pendidikan. Untuk tingkat dasar, filosofi konservatif seperti esensialisme dan perenialisme haruslah dapat diubah ke filosofi yang lebih menekankan pendidikan sebagai upaya mengembangkan kemampuan kemanusiaan peserta didik baik sebagai individu maupun sebagai anggota masyarakat bangsa, dan dunia. Filosofi kurikulum yang progresif seperti humanisme, progresifme, dan rekontruksi sosial dapat dijadikan landasan pengembangan kurikulum.

Kedua, teori kurikulum tentang konten (curriculum content) haruslah berubah dari teori yang mengartikan konten sebagai aspek substantif yang berisikan fakta, teori, generalisasi kepada pengertian yang mencakup pula nilai, moral, prosedur, dan ketrampilan yang harus dimiliki generasi muda.

Ketiga, teori belajar yang digunakan dalam kurikulum masa depan yang memperhatikan keragaman sosial, budaya, ekonomi, dan politik tidak boleh lagi hanya mendasarkan diri pada teori psikologi belajar yang bersifat individualistik dan menempatkan siswa dalam suatu kondisi value free, tetapi harus pula didasarkan pada teori belajar yang menempatkan siswa sebagai makhluk sosial, budaya, politik, dan hidup sebagai anggota aktif masyarakat, bangsa, dan dunia.

Keempat, proses belajar yang dikembangkan untuk siswa haruslah pula berdasarkan proses yang memiliki tingkat isomorphism yang tinggi dengan kenyataan sosial. Artinya, proses belajar yang mengandalkan siswa belajar individualistis harus ditinggalkan dan diganti dengan cara belajar berkelompok dan bersaing secara kelompok dalam suatu situasi positif. Dengan cara demikian maka perbedaan antarindividu dapat dikembangkan sebagai suatu kekuatan kelompok dan siswa terbiasa hidup dengan berbagai keragaman budaya, sosial, intelektualitas, ekonomi, dan aspirasi politik.

Kelima, evaluasi yang digunakan haruslah meliputi keseluruhan aspek 
kemampuan dan kepribadian peserta didik, sesuai dengan tujuan dan konten yang dikembangkan. Alat evaluasi yang digunakan haruslah beragam sesuai dengan sifat tujuan dan informasi yang ingin dikumpulkan. Penggunaan alternatif assesment (portfolio, catatan, observasi, wawancara) dapat digunakan.

Di samping perlunya memperhatikan langkah-langkah itu, untuk menuju sebuah PAI yang menghargai pluralisme, sebenarnya selain aspek kurikulum yang harus didesain, sebagaimana telah penulis uraikan, aspek pendekatan dan pengajaran. Polapola lama dalam pendekatan atau pengajaran agama harus segera dirubah dengan model baru yang lebih mengalir dan komunikatif. Aspek perbedaan harus menjadi titik tekan dari setiap pendidik. Pendidik harus sadar betul bahwa masing-masing peserta didik merupakan "manusia yang unik" (human uniqe), karena itu tidak boleh ada penyeragaman-peyeragaman. Dalam prespektif ini, pendidikan agama Islam yang memberikan materi kajian perbandingan agama dan nilai-nilai prinsip Islam seperti; toleransi, keadilan, kebebasan dan demokrasi — untuk memperoleh suatu pemahaman di antara orang-orang yang berbeda iman itu—adalah sebuah keniscayaan.

\section{MENAMPILKAN ISLAM TOLERAN MELALUI KURIKULUM}

Mengembangkan sikap pluralisme pada peserta didik di era sekarang ini, adalah mutlak segera "dilakukan" oleh seluruh pendidikan agama di Indonesia demi kedamaian sejati. Pendidikan agama Islam perlu segera menampilkan ajaran-ajaran Islam yang toleran melalui kurikulum pendidikanya dengan tujuan dan menitikberatkan pada pemahaman dan upaya untuk bisa hidup dalam konteks perbedaan agama dan budaya, baik secara individual maupun secara kolompok dan tidak terjebak pada primordialisme dan eklusifisme kelompok agama dan budaya yang sempit. Menurut Azyumardi Azrah bahwa sikap-sikap pluralisme itu akan dapat ditumbuhkembangkan dalam diri generasi muda melalui dimensi-dimensi pendidikan agama, ${ }^{14}$ dengan memperhatikan hal-hal seperti berikut:

a. Pendidikan agama seperti fiqih, tafsir tidak harus bersifat linier, namun menggunakan pendekatan muqaron. Ini menjadi sangat penting, karena anak tidak hanya dibekali pengetahuan atau pemahaman tentang ketentuan hukum dalam fiqih atau makna ayat yang tunggal, namun juga diberikan pandangan yang berbeda. Tentunya, bukan sekedar mengetahui yang berbeda, namun juga diberikan pengetahuan tentang mengapa bisa berbeda.

b. Untuk mengembangkan kecerdasan sosial, siswa juga harus diberikan pendidikan lintas agama. Hal ini dapat dilakukan dengan program dialog antar agama yang perlu diselenggarakan oleh lembaga pendidikan Islam . Sebagai contoh, dialog tentang "puasa" yang bisa menghadirkan para bikhsu atau agamawan dari agama lain. Program ini menjadi sangat strategis, khususnya untuk memberikan

14 Azyumardi Azra, 1998, Esai-esai Intelektual Muslim dan Pendidikan Islam, Tradisi dan Modernisme Menuju Milenium Baru, h. 159-160. 
pemahaman kepada siswa bahwa ternyata puasa itu juga menjadi ajaran saudarasaudara kita yang beragama Budha. Dengan dialog seperti ini, peserta didik diharapkan akan mempunyai pemahaman khususnya dalam menilai keyakinan saudara-saudara kita yang berbeda agama. karena memang pada kenyataanya "Di Luar Islampun Ada Keselamatan".

c. Untuk memahami realitas perbedaan dalam beragama, lembaga-lembaga pendidikan Islam bukan hanya sekedar menyelenggarakan dialog antar agama, namun juga menyelenggarakan program road show lintas agama. Program road show lintas agama ini adalah program nyata untuk menanamkan kepedulian dan solidaritas terhadap komunitas agama lain. Hal ini dengan cara mengirimkan siswasiswa untuk ikut kerja bhakti membersihkan gereja, wihara ataupun tempat suci lainnya. Kesadaran pluralitas bukan sekedar hanya memahami keberbedaan, namun juga harus ditunjukkan dengan sikap konkrit bahwa diantara kita sekalipun berbeda keyakinan, namun saudara dan saling membantu antar sesama.

d. Untuk menanamkan kesadaran spiritual, pendidikan Islam perlu menyelenggarakan program seperti spiritual work camp (SWC), hal ini bisa dilakukan dengan cara mengirimkan siswa untuk ikut dalam sebuah keluarga selama beberapa hari, termasuk kemungkinan ikut pada keluarga yang berbeda agama. Siswa harus melebur dalam keluarga tersebut. Ia juga harus melakukan aktifitas sebagaimana aktifitas keseharian dari keluarga tersebut. Jika keluarga tersebut petani, maka ia harus pula membantu keluarga tersebut bertani dan sebagainya. Ini adalah suatu program yang sangat strategis untuk meningkatkan kepekaan serta solidaritas sosial. Pelajaran penting lainnya, adalah siswa dapat belajar bagaimana memahami kehidupan yang beragam. Dengan demikian, siswa akan mempunyai kesadaran dan kepekaan untuk menghargai dan menghormati orang lain.

e. Pada bulan Ramadhan, adalah bulan yang sangat strategis untuk menumbuhkan kepekaan sosial pada anak didik. Dengan menyelenggarakan "program sahur on the road", misalnya. Karena dengan program ini, dapat dirancang sahur bersama antara siswa dengan anak-anak jalanan. Program ini juga memberikan manfaat langsung kepada siswa untuk menumbuhkan sikap kepekaan sosial, terutama pada orang-orang di sekitarnya yang kurang mampu.

\section{KESIMPULAN}

Kalau tujuan akhir pendidikan adalah perubahan perilaku dan sikap serta kualitas seseorang, maka pengajaran harus berlangsung sedemikian rupa sehingga tidak sekedar memberi informasi atau pengetahuan melainkan harus menyentuh hati, sehingga akan mendorongnya dapat mengambil keputusan untuk berubah. Pendidikan agama Islam, dengan demikian, di samping bertujuan untuk memperteguh keyakinan pada agamanya, juga harus diorientasikan untuk menanamkan empati, simpati dan solidaritas terhadap sesama. Maka, dalam hal ini, semua materi buku-buku yang diajarkannya tentunya 
harus menyentuh tentang isu pluralitas. Dari sinilah kemudian kita akan mengerti urgensinya untuk menyusun bentuk kurikulum pendidikan agama berbasis pluralisme agama.

\section{DAFTAR PUSTAKA}

Afifi, al-Hadi, Muhammad, (1964), al-Tarbiyah wa al-Taghoyyur al-Tsaqafi, Kairo: Maktabah Angelo al-Mishriyyah.

Allen, Dougles, 1978, Structure and Creativity in Religion. The Houge the Netherlands: Mountan Publisher.

Arkoun, Mohammed, 2001, Islam Kontemporer: menuju Dialog antar agama, Yogyakarta: Pustaka Pelajar.

Abdullah, Amin, M., (1999), Studi Agama: Normativitas atau Historisitas, Yogyakarta: Pustaka Pelajar.

Azra, Azyumardi, 1998, Esai-esai Intelektual Muslim dan Pendidikan Islam, Tradisi dan Modernisme Menuju Milenium Baru, Jakarta: Logos Wacana Ilmu.

Barnadib, Imam, 1994, Filsafat Pendidikan: Sistem dan Metode, Yogyakarta, Andi Ofset.

Basri, Ghazali at al, 1991, An Integrated Education System In A Multifaith and MultiCultural Country, Malaysia: Muslim Yuth Movement Malaysia.

Basuki, Singgih, A., 1999. "Kesatuan dan Keragaman Agama Dalam Pandangan Hazrat Inayat Khan", dalam Jurnal Penelitian Agama, Nomor 21, TH. VIII Januari-April.

Beck, Clive, 1990., Better Schools: A Value Perspective, Britain: The Falmer Press, Taylor and Francis ICC.

Bogdan, Robert, C. and Biklen, Knoop, Sari, Qualitative Research for Education, an Introduction to Theory and Methode, Boston: Allyn and Bacon, 1993 